Stanisław Juszczyk

Poland

Mária Karasová

Slovakia

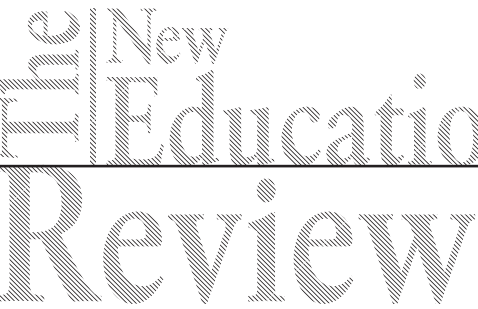

Mária Jurečková

Slovakia

Miriam Uhrinová

Slovakia

\title{
Interest of Primary Education Teachers in Media Education and Their Attitudes Towards Further Education in Slovakia
}

DOI: 10.15804/tner.2021.64.2.17

\begin{abstract}
Within the context of lifelong learning, it is necessary for teachers to improve their competencies, including the competencies in the use of digital media. The paper presents partial results of research carried out within the VEGA 1/0913/15 project on Media Literacy of Young School-Age Children in the Context of Family and School Cooperation, while it also analyses the need to develop digital literacy, which is part of the VEGA 1/0748/20 project on Diagnosing Digital Literacy of Primary School Teachers in the Context of Undergraduate Training and Educational Reality. The empirical research had a diagnostic as well as quantitative and qualitative character. The subject of the research was media education of younger school-age pupils implemented in both formal and informal ways in Slovakia. The research involved 28 schools from all over Slovakia. The paper focuses mainly on the findings obtained from the questionnaires filled out by primary school teachers, interviews conducted with school management and content analysis of school educational programs. It focuses primarily on the interest of teachers in further training in media education.
\end{abstract}

Keywords: media education, teacher, media literacy, digital literacy, Slovakia 


\section{Introduction}

The trend of getting to know the media world and using associated technologies is expanding among younger and younger children. They were born into a world linked with modern technologies. It is natural for them to use mobile phones, related applications or the Internet. They do not need to be taught how to use them. However, due to a declining in the age when a child is first exposed to media, the opposite problem arises. Are they mature enough or able to use media responsibly and to their benefit? Can they get oriented in the immense amount of information being poured into them which they can critically evaluate? The outlined problems point out the need for the implementation of media education, even in pre-school education. The first contact smartphone, tablet, and digital game trends are changing rapidly. The games that children used to play at the age of $7-8$ years are now played by 5 -year-old children. Therefore, it is essential to develop digital, as well as media and information literacy. The connection between the two is obvious. We are functioning in a digital society where children and young people should, in school and beyond, develop digital skills related to the correct use of digital technologies in education, teamwork, social communication, the development of diverse interests and future professional work. That is why it is so important to educate teachers in the media, whether in university or postgraduate studies, so that they can shape their pupils' digital competencies (Fallon, 2020).

The media education in Slovakia has been developed in a targeted way since 2008. Although more than 10 years have passed since then, we see the need to educate teachers as well as parents in this area. Insufficient attention is paid to pre-school and younger school age in particular. Many research studies in Slovakia focus primarily on the older age category (Petranová, Vrabec, 2015, Kačinová, Kolčáková, 2013, etc.). For all these reasons, we focused on the category of younger school age. In this paper we present the results of the research we conducted in Slovakia in 2016 - 2017. Also based on the obtained results, we see the need for teachers to go more in depth when educating pupils on the issue, which is also related to digital literacy.

The paper reflects the need for media education, which is also associated with the acquisition of digital literacy as well as information literacy, especially among parents and teachers.

\section{Research Focus}

On one hand, media simplifies lots of things and provides instant access to an abundance of information, on the other hand irresponsible use deprives us of 
much time and real life experiences. Besides parents, teachers are second most important authority for children, who contribute to the creation and formation of the child's personality. Every teacher should work on improving their media and digital literacies so that they can develop them in pupils as well. „Although there are new media and literacies in the current constellation, books, reading, and print literacy continue to be of utmost significance. Indeed, in the current information/communication technology environment traditional print literacy takes on increasing importance in the computer-mediated cyberworld as people need to critically scrutinize and scroll tremendous amounts of information, putting new emphasis on developing reading and writing abilities." (Kellner, Share, 2005, p. 370) Within the context of the current situation, information analysis and the need to develop critical thinking and problem solving skills are even more important.

In Slovakia, we encounter several problems related to the ICT implementation in education. It is primarily a one-sided use of digital media without taking advantage of its true potential, as well as an excessive use, which results in several consequences (related to health effects; pupils relying on Google as the only source of information; etc.). The given reasons indicate the importance of the personality of the teacher and his/her personal contribution to the instruction process. (Karasová, 2014). The use of digital, personalized and interactive devices even by preschool children has increased sharply in recent years, all the more so in the case of older children (Chaudron, 2015; Plowman, Stevensom, Stephen, McPake, 2012). This is also reflected in the use of ICT in education, which is the subject of a number of studies and research from pre-primary education and primary education (e. g. Estyn, 2013; Tay, Lim, Lim, Koh, 2012; Balanskat, 2009; Sarkar, Mohapatra, Sundarakrishnan, 2017; Higgins, 2003; Juszczyk, 2004; Juszczyk \& Kim, 2015, 2018 ; Juszczyk, Karasová, 2017; Círus, 2016, 2017; Kalaš, 2011; Karasová, 2017, 2019; Šupšáková, 2016, Izrael, Karasová, Yang, 2020) to higher education. The research results indicate that in younger school-age children there is a considerable interest in television and the Internet in particular (with priority to PC games, YouTube and social networks).

This is also shown by the research carried out in Slovakia in 2013-2014. The most preferred medium for children of younger school age is television, taking into account that they watch it for two or more hours a day on a normal basis (Šupšáková, 2016). The frequency of children's contact with digital media is growing and intensified by distance education in the current situation with prevailing online learning. The consequences will become apparent over a longer period of time so it is necessary to study them. 
The development of digital literacy is an ongoing process, across all levels of education, not excluding adult education. ICT skills are nowadays related to the use of the media, especially the Internet. Therefore, the acquisition of digital literacy is also intertwined with the acquisition of media and information literacies. For all these reasons, it is therefore necessary for teachers to develop competencies in these areas. Thanks to this, we can shape pupils more in the field of prevention against the negative phenomena associated with the use of digital media and teach them to behave responsibly and safely.

\section{Methodology of Research}

\section{General Background of Research}

Empirical research had a diagnostic as well as quantitative and qualitative character. The subject of the research was media education in younger school-age pupils implemented in both formal and informal ways in Slovakia and the level of media literacy of primary school pupils, cooperation between school (teachers) and family in the area of media education and shaping good habits of younger school-age children. The paper focuses primarily on presenting the research results from the teachers' perspectives and the implementation of media education in the first stage of primary school.

The cognitive goals of the research also included the following goals:

- To find out the current state of the implementation of media education at the primary stage of primary schools in Slovakia,

- To find out the current state in the area of readiness of primary education teachers when implementing media education in primary education,

- To analyse the views of primary education teachers of the need for media education at primary schools.

The beginning point for our research were the following research questions:

RQ1: What are the attitudes of primary education teachers towards media school? education at primary

RQ2: Do the teachers' attitudes towards the need for media education in primary education depend on the size of the locality in which they work?

RQ3: What is the interest of primary education teachers in training in media education?

RQ4: Do primary education teachers use elements of media education in class? 


\section{Sample of Research}

A number of 28 primary schools were selected for the research. When selecting schools, we took into account the size of the localities in which the schools were located, based on the following categories: 9 schools in the category up to 4.999 inhabitants, 11 schools in the category from 5.000 to 99.999 inhabitants, and 8 schools in big cities over 100.000 inhabitants. Among the selected schools were: 9 church schools, 2 private schools and 17 state schools.

The research involved 151 primary education teachers ( 5 men and 146 women), 27 head teachers or deputy head teachers. A total of 48 focus group interviews were conducted and in each of the target groups there were 10 third-year primary school pupils (480 pupils). The research also involved 498 parents (92 men and 406 women).

\section{Instrument and Procedures}

The method of diagnostic research was used as the basic method in empirical research. A questionnaire addressed to teachers and parents as well as categorized interviews (i.e. such interviews where questionnaires contain the same questions in the same unaltered order to be asked by the same respondent from the same professional or social group) with school principals or representatives were used. A focus group interview was conducted with pupils, in which the moderators were members of the VEGA research team (these were teachers with high qualifications in working with children), which determined the qualitative aspect of our research.

\section{Data Analysis}

For the quantitative analysis of the results, selected statistical procedures were used to process the data from the questionnaire. The distribution of relative frequencies is presented in the form of contingency graphs. To determine the dependence or independence of selected variables, Pearson's Chi-square test of independence was used.

\section{Results of Research}

We wanted to find out the attitudes of primary education teachers towards media education at primary schools. From the following graph (Figure 1) we can conclude that more than $72 \%$ of respondents, who are primary education teachers consider media education to be a necessary part of primary school education. 


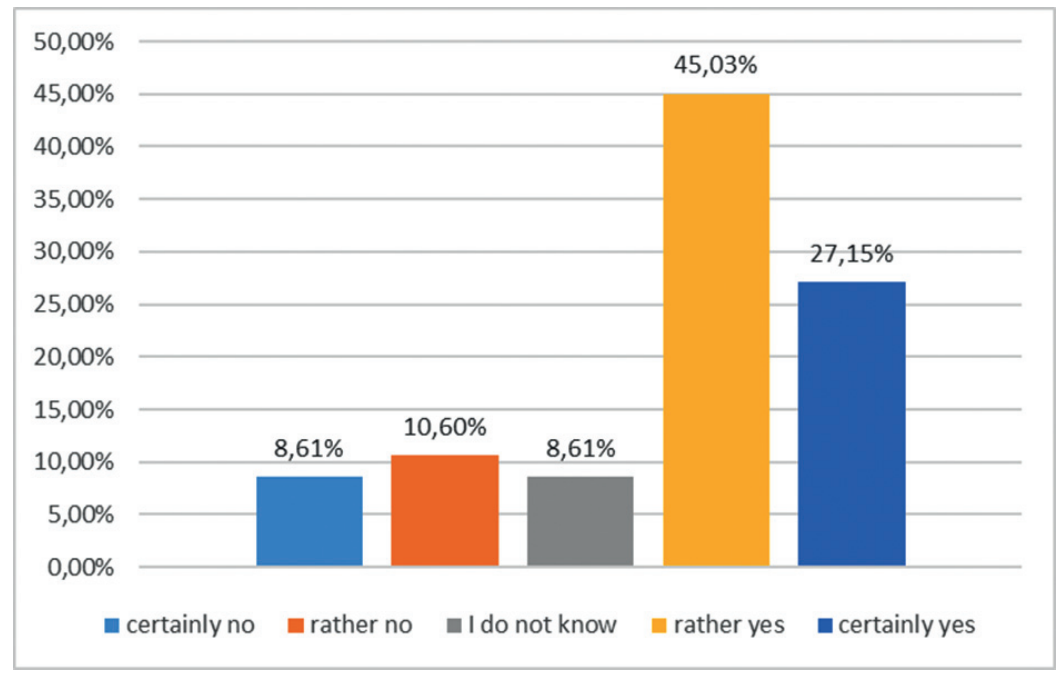

Figure 1. Attitudes of primary education teachers towards media education

Based on the analysis of qualitative data, it was surprising for us to find that the implementation of media education in schools significantly lags behind the declared need for media education. It has been shown that teachers implement media education in a very diverse intensity and scope. We also met with teachers who priorly perceive media education as the use of computers and other devices in education. However, more teachers, on the other hand, implement media education intuitively, based on experience and the need to influence pupils in the area of creating values. This was quite often connected with the topics through which teachers drew attention to selected problems associated with uncritical use of the media (topics related to personal data protection, cyberbullying, disinfection, etc.).

We wanted to find out whether the teacher's attitudes towards the need for media education in primary education is influenced by the size of the locality in which they work. In the questionnaire, we monitored the size of the town or city where the respondent works as a teacher. We divided localities into three categories based on population, as mentioned above (1: up to 4,999 inhabitants, 2: 5,000-99,999, 3: more than 100,000).

From the graph (Figure 2) constructed based on our research sample, we can state that the need for media education grows with the size of the locality where the teacher works. 


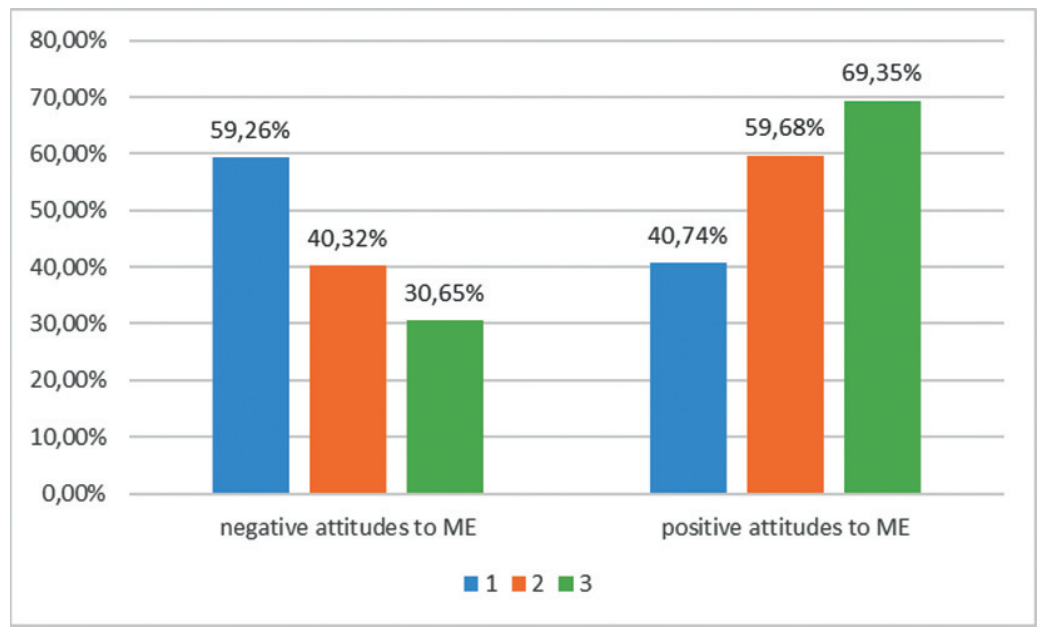

Figure 2. Teachers' attitudes towards media education according to the size of the locality

At a significance level of $p<0.05$, we verified the significance of this difference using the Chi - square test. The p-value for this test is 0.039 , which confirms the significance of the observed difference.

We can state that the teacher's attitudes towards the need for media education in primary education is influenced by the size of the locality where they work: teachers from larger cities are more likely to report the need for media education.

What is the interest of primary education teachers in training in media education? Approximately $53 \%$ of respondents were interested in training in media education. More detailed results can be seen in Graph 3.

According to our expectations, the interest of teachers in training was higher among the respondents with a positive attitude towards media education (62.96\%). In the case of the teachers with a negative attitude, it was less than $28 \%$. The significance of the observed differences was also confirmed by the p-value of the Chi-square test (test value $\mathrm{X}=0.000098$, according to $\mathrm{p}<0.05$ ).

Up to $62.3 \%$ of the sample of the teachers we studied use self-education in the field of media education. However, it is not clearly guaranteed whether they come into contact with relevant information and resources. Therefore, we consider training carried out by experts to be one of the solutions. Another solution can also be educational portals for teachers. There are already several such portals in Slovakia (Zodpovedne.sk, www.medialnavychova.sk, www.detinanete.sk, etc.) containing materials also intended for teachers. However, they are primarily aimed 


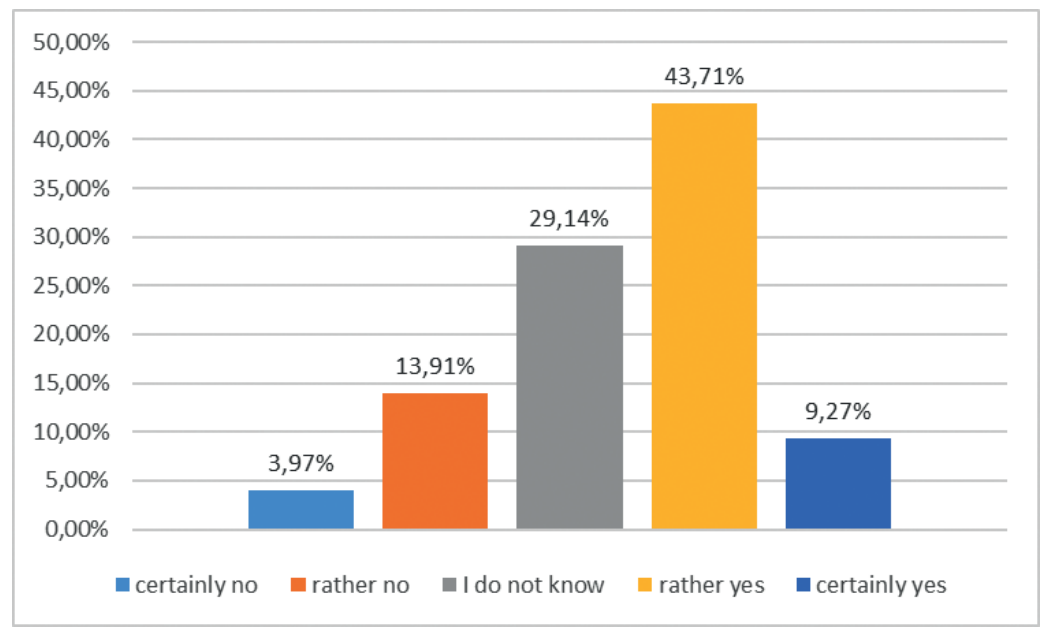

Figure 3. Interest of primary education teachers in media education training

at a wider audience, they are mainly divided into categories for parents, teachers and children. Teachers most often stated that they lacked methodological manuals that would help them to implement media education better in practice.

We also wanted to know if primary education teachers use elements of media education in class. It is clear from the following graph that the use of elements of media education is dominant not only for teachers who declare the need for media

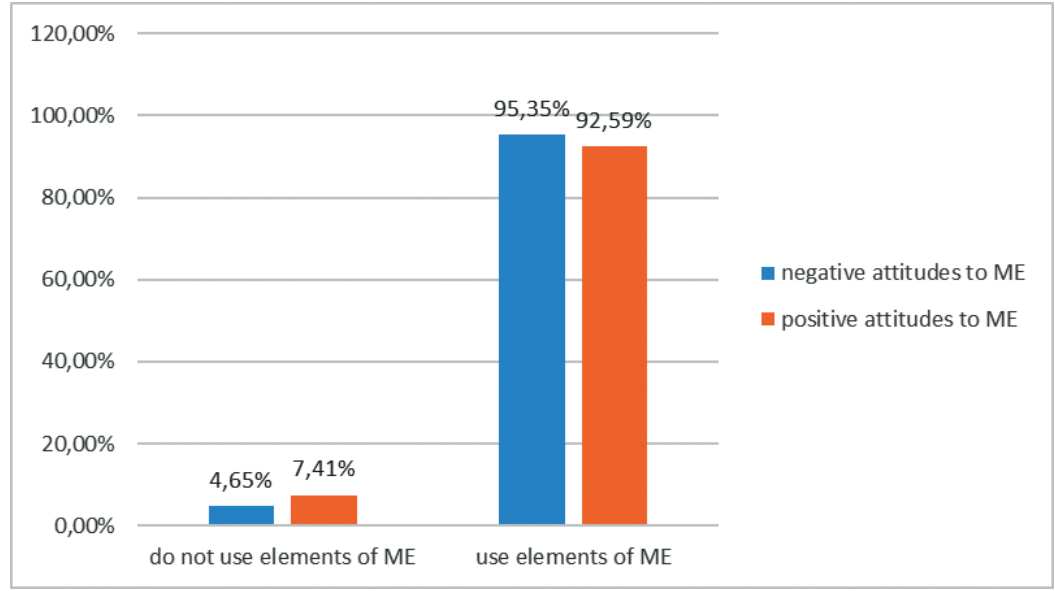

Figure 4. The use of media education elements based on teachers' attitudes towards media education 
education in primary education, but also for those who tend to incline towards the opposing view.

The fact that the use of elements of media education is not influenced by teacher's attitudes towards the need for media education in primary education was also verified at the level of significance $\mathrm{p}<0.05$ with the Chi-square test ( $\mathrm{p}$-value $=0.54$ ).

The following graph (Figure 5) indicates that the use of elements of media education is not affected by the size of the locality. This indication was also confirmed by the $\mathrm{p}$-value of the Chi-square test $(0.122)$ at the level of significance $\mathrm{p}<0.05$. We can therefore state that the use of elements of media education in class is not affected by the size of the locality in which the school is located.

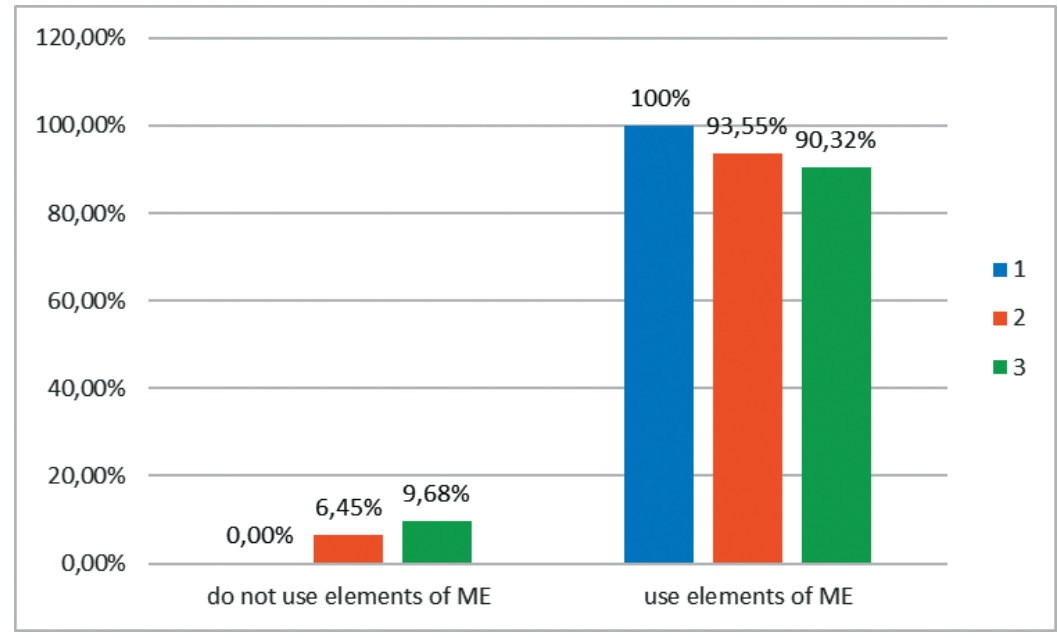

Figure 5. Use of media education elements according to the size of the locality

Most often the teachers said that they worked with print media (books, children's magazines) and that they were equipped and worked with digital media, especially computers, or interactive whiteboards. It is interesting that teachers involved work with the media more often than using discussion and practical activities aimed at developing critical thinking in media environments. As stated above, the use of digital media by teachers is related to misunderstanding of the content and purpose of media education. In interviews with teachers, we observed that some considered it natural to warn pupils of the dangers concerning their contact with the media. Teachers are aware of the risks associated with the excessive use of digital media and they monitor changes in pupils' behaviour during their practice. 
Within this context, it is also confirmed by the results of a research project carried out by the International Media Literacy Centre IMEC in 2011/2012. The results show that we do not have enough qualified teachers to teach media education in Slovakia (Kačinová, Kolčáková, 2013). With regard to a year of research, the situation is constantly progressing, therefore we want to update the data within the project that we are implementing.

From interviews with school management, we found out that the projects focused on the implementation of media education in primary education were implemented only to a minimum extent. More attention is mainly paid to media education at the second stage of primary school, or it is teachers' own initiative to spend some time with this issue within the subject of informatics. Occasionally there will be a possibility within the after school activities/clubs. The given facts confirm that it mainly depends on the specific teacher as to how much time they devote to implementation of media education at the first stage of primary school. The interview also indicates a problem that teachers are not completely certain what can be considered as media education. One of the reasons is the rapid informatization of education, which has resulted in excessive use of digital technologies in the educational process and teachers do not perceive the difference between media and digital literacy, or tend to prefer the concept of using ICT. We met more often with the attitude of teachers who implement media education by using an interactive whiteboard. Failure to understand the concepts, content as well as the objectives of the subject of media education results in the use of computers and other devices in class, but not in education for responsible and safe use of the media. None of the schools we studied focuses primarily on media education. The interview as well as our analysis of school curricula show that schools focus mainly on traffic, regional and environmental educations. Several schools enhanced the classes of English or computer science education with increased time allocations. We appreciate the efforts of some schools to invite a psychologist to the plenary parent-teacher meetings, who dealt specifically with the issue of the media's influence on children's behaviour and cyberbullying. However, this was mostly occasional in our research sample, because parents did not show enough interest, as reported by the management.

\section{Discussion}

The research findings show that teachers are interested in education in the given problematics, they lack methodological manuals in particular. The need for imple- 
mentation of media education elements is growing with the size of the locality where teachers work. More than half of teachers are interested in training in this area. The use of media education elements is dominant not only among teachers who declare the need for media education in primary education, but also among those who tend to incline towards the opposing view. The use of elements of media education is not affected by the size of the school locality (Figure 5).

The teachers' attitudes towards and their interest in media education are related to its actual implementation. If a teacher does not show sufficient interest, media education is implemented to a minimum level.

The current situation in the world has caused many teachers to shift to necessary (forced) online teaching, the consequences of which need to be further studied. Even due to the current situation, teachers deepened their digital competencies. Online teaching has brought several possibilities for its implementation. Some teachers prefer offline methods in particular. Based on our findings, a certain degree of insufficient knowledge base related to media literacy and its development is shown. The idea of some teachers about media education is limited to the use of computers and other devices in class, which eliminates the possibility of developing pupils' critical and analytical thinking (Figure 1).

From the focus group interviews conducted with the pupils, we found that pupils prefer watching television and activities related to the use of the Internet. A significant number of children reported watching inappropriate series and programs on television (series, crime series, reality shows), yet the popularity of fairy tale films and animated films persists. In the case of the Internet, we observe mainly three areas of interest in children. These are mainly computer games (online and offline), YouTube and the related watching of YouTubers, and the use of social networks. The interest in PC games is mainly among first and second-year primary school pupils. Third and fourth-year primary school pupils prefer social media related networks for messaging and YouTube. In addition to these preferences, school children of all ages use the Internet to search for information related to school projects. It can be stated that there has been a shift in the interest of children today in favour of the Internet and social networks, which is also partly indicated based on the results of our research. Children are not only interested in computer games, but also in YouTubers and social networks, which are more attractive phenomena. Due to the above facts, we also consider it necessary to support the development of teachers' competencies related to the use of digital media. 


\section{Conclusions}

The implemented research shows the need for education in the field of media and related digital competencies. Nowadays, pupils have no problem using technology or any new means preferably displaying digital content. The problem has been shown at the level of critical and analytical thinking skills. We also see possible connections between the insufficient development of communication competencies and, above all, problems with reading comprehension. The possible consequences are evident from the amount of video and audio-visual content which is used more often than textual information offered mainly through traditional media, especially books. For all these reasons, there is a need to develop classic, not just digital skills. That is why we consider it necessary to develop media and digital competencies with regard to the priority need to improve classic skills (we mean the development of social and communication skills in particular, as well as reading literacy and fine motor skills, etc.).

At present, it is also necessary to cope with the overload resulting from almost constant contact with the media. This is related to the pandemic situation in which a large number of people and also teachers work from home and thus are in almost constant contact with the media, which is caused in several time intervals also in Slovakia. The consequences can already be observed not only in adults, but especially in children and adolescents.

People feel exhausted and overwhelmed, which is partly related to the fact that all activities are connected to their homes. The problem is that all social roles (such as a colleague, husband, family member, etc.) suddenly collapsed and narrowed down into a household in front of the screen, making us more susceptible to emotional fluctuations. At the same time, in the interaction in front of the camera we tend to focus and work on networking more intensively, we have to create much more non-verbal stimuli. In addition, technologies also bring problems associated with delayed response, signal or connection strength, and problems are also associated with the ever-present profound digital differences in society (Deuze, 2020). This is also reflected in the work of the teacher, especially in primary education. Keeping pupils' attention via a webcam for about 30 minutes and then connecting to another subject is challenging not only for lesson planning, but also for concentration and creativity. As a result of the pandemic situation, we see that differences in the use of technology in schools are even more pronounced, and we are also aware of the overload that is also currently visible in teachers. It is very difficult to fully implement many of the skills that pupils have to acquire especially in the first years of primary school by means of digital media. The time 
children spend on screens also multiplies. Further studies may show the extent to which online education and the reduction of real peer contacts have influenced children and affected their behaviour. This fact also shows the need for acquisition of media and digital competencies in teachers. We do not mean only the control of programs and communication channels, above all it is important to help children acquire classic skills and learn to think critically, as well as to use digital media in a reasonable way so that they are not lost in a digital world full of diverse information.

Our findings, as well as the current situation, show the interconnectedness and close link between digital and media literacies, which is reflected in the ongoing VEGA 1/0748/20 research project on Diagnosing Digital Literacy of Primary School Teachers in the Context of Undergraduate Training and Educational Reality.

\section{References}

Balanskat, A. (2009). Study of the impact of technology in primary school. Synthesis Report. Brussels: STEPS EACEA.

Círus, L. (2016). Relationship between type of teacher with respect to adoption of innovation in ICT and level of computer skills of primary school pupils. In SGEM 2016: $3 r d$ international multidisciplinary scientific conference on social sciences \& arts, 3(1), 825-832. DOI: 10.5593/SGEMSOCIAL2016/B13/S03.108

Círus, L. (2017). Diagnostics of Teachers at the First Grade of Primary School with Respect to Acquisition of Innovative Skills in ICT. In Media4u Magazine, 14(1), 24-28.

Círus, L., Maňenová, M. \& Škoda, J. (2019). Teachers' attitudes towards ICT and their reflection in the pupils' digital literacy. Ústí nad Labem: EDUCA PF UJEP.

Deuze, M. (2020). The Role of Media and Mass Communication Theory in the Global Pandemic. Communication today, 11(2), 4-16.

Fallon, G. (2020). From digital literacy to digital competence: the teacher digital competence (TDC) framework. Educational Technology Research and Development, 66, pp. 2449-2472.

Higgins, S. (2003). Does ICT improve learning and teaching in schools? Newcastle: Newcastle University.

Chaudron, S. (2015). Young Children (0-8) and Digital Technology. A qualitative exploratory study across seven countries. Luxembourg: Joint Research Centre.

Izrael, P., Karasová, M., Yang, M. (2020). Parental Mediation of Digital Media Use Among Children Aged 3-8 from the Perspective of Parents' Media Competence. The New Educational Review, 60(2), 27-38. DOI: 10.15804/tner.2020.60.2.02

Juszczyk, S. (2004). Media influence on children and adolescents. The New Educational Review, 2(3), 93-112.

Juszczyk, S., Karasová, M. (2017). Analýza súčasného stavu mediálnej výchovy u detí 
mladšieho školského veku (Analysis of the current state of media education in children of younger school age). Ružomberok: Verbum.

Juszczyk, S., Kim YD. (2015). Social roles and competences of a teacher in a virtual classroom in Poland and Korea. The New Educational Review, 42(4), 153-164.

Juszczyk, S., Kim, S. (2018). The Polish and Korean Youth in the World of Digital Media: Communication and Interests. A Comparative Analysis. The New Educational Review, 52(2), 124-136. DOI: 10.15804/tner.2018.52.2.10

Kačinová, V. \& Kolčáková V. (2013). Súčasný stav začlenenia mediálnej výchovy do obsahu vzdelávania na základných školách na Slovensku. (The current State of integration of Media Education into the Content of Education at Primary Schools in Slovakia). Trnava: IMEC.

Karasová, M. (2014). In adequate use of modern Information and communication technology in primary education and options of its use. In Scientia: early school education exemplifications in practice. Chełm: PWSZ w Chełmie, No. 8, 41-48.

Karasová, M. (2019). Computer games in the life of a younger school age children. In: Podejścia metodologiczne $w$ pedagogice : koncepcje - badania - wyniki. Katowice: Wydawnictwo Uniwersytetu Śląskiego, 151-160.

Kellner, D. \& Share, J. (2005). Toward Critical Media Literacy: Core concepts, debates, organizations, and policy. In Discourse: studies in the cultural politics of education, 26(3), 369-386.

Petranová, D. \& Vrabec, N. (2015). Mediálna gramotnost' dospelej populácie v SR. (Media Literacy of the Adult population in SVK). Trnava: FMK UCM.

Plowman L., Stevenson, O., Stephen, C. \& McPake, J. (2012). Preschool children's learning with technology at home. Computers \& Education, 59(1), 30-37.

Sarkar, S., Mohapatra, S. \& Sundarakrishnan, J. (2017). Information and Communications Technology in Primary School Education. Switzerland: Springer International Publishing AG.

Šupšáková, B. (2016). Media Education of Children and Youth as a path to Media Literacy. Communication Today, 7(1), 32-51.

Tay, L. Y., Lim, K. S., Lim, P. CH. \& Koh, L. J. H. (2012). Pedagogical approaches for ICT integration into primary school English and mathematics: A Singapore case study. Australasian Journal of Educational Technology, 2012, 28(4), 740-754.

The impact of ICT on pupil's learning in primary schools. Cardiff: Estyn, 2013. Retrieved 3/08/2005, from https://www.estyn.gov.wales/ 